DOI:10.5937/ZRFFP44-7092

\author{
TANJA T. PRODOVIĆ ${ }^{1}$ \\ UNIVERSITY OF KRAGUJEVAC, FACULTY OF MEDICAL SCIENCES \\ DRAGANA IGNJATOVIĆ RISTIĆ \\ Psychiatric Clinic, Clinical Center Kragujevac \\ Biljana T. Prodović MILOJKOVIĆ \\ UNIVERSITY OF NIš, FACULTY OF PHILOSOPHY
}

\title{
BIO-PSYCHO-SOCIAL CONCEPT OF AGEING ${ }^{2}$
}

\begin{abstract}
The paper focuses thematically on one of the essential issues of human existence, a complex and a mysterious phenomenon of ageing. The old people with their biological and psychological features, with their social position and other aspects, are the inexhaustible source of professional research of doctors and sociologists. As opposed to the usual pessimistic attitude of ageing and the old age, the paper points, within the humanist and social work frame, to man's awareness of overcoming the transience of human existence by cultivating a sense and a beauty of life. By elaborating on the concept of ageing, the authors stress the length and the quality of life, which could be advanced by the interaction of three groups of factors: social engagement and participation, the reduction of illness and the improvement of the high level of psychological and mental functions.
\end{abstract}

KEY WORDS: old age, ageing, demography, social issues, health issues.

1 tanjaprodovic@gmail.com

2 Рад је примљен 6. октобра 2014, а прихваћен за објављивање на састанку Редакције 3ठорника одржаном 25. децембра 2014. 
"Nothing is more changeable than the outlines of ageing, that physiologicalpsychological-social complexity. Does the man have the years of his veins, heart, brain, his spirit or his personal data? Or is it the attitude of others that one dayt classifies us as old people?"

Georges Minois

\section{INTRODUCTION}

The thematic program of this paper should contain essential issues of human existence. And this multiple problem, scientifically based and institutionally practiced, is mainly limited, conditioned by a thoughtfully restrained philosophical paradigm which often misses its essence - of this great unknown phenomenon (Petrickovic, 2012). The text poses a question of the essence which marks differentiu specific of the ageing phenomenon, not coming down to its well-known and legally accepted dimensions, like illness, weakness, dependence, dissatisfaction, misfortune, temporality, absurdity, and other pessimistic alternatives of human existence.

It is about rationally accepted ageing as the result of the universal material and spiritual transformation of everything that exists in the cosmos, the mankind and an individual, which is determined by the impeccable natural laws, is subject to the inevitable universal natural cycle: existence, endurance, death, which is not sufficient enough reason for a man as a conscious being to find the minimum of creative imagination and the beauty of living, according to some logical laws (Jaspers, 2008).

Ageing and old age reflect two diverse emergent and informative forms: individual and social.

Ageing and an individual old age is the function of life lapse. It's an individual bio-psycho-social phenomenon and it represents a natural life phase with all its characteristics, and not illness. Starting from birth, every individual begins to age with the time passing and many changes of physical and mental characteristics as well as of social functions of an individual emerge. As the time passes, ageing could be considered the process of maturing.

Aging and age society (population), however, with respect to demographics, age observed at the global level and have very precise numerical criteria in their definition (demographic trends within the changing age structure, reducing the birth rate, extending the life) (Milosavljevic, 2011). 
Many difficulties arise while defining the phenomenon of ageing mostly because of the lack of the ultimate answer to the essence of ageing. There is not one generally accepted theory but the dogmatic attitude about the loss of something and a complete transience. Therefore, there are many definitions of the notion of individual ageing with significant differences in regard to the scientific and research orientation of the author as well as to the differences in social norms, the nature of belief, etc. (Kastenbaum, 1986).

It is important to emphasize the differences in defining ageing when gerontology as science gives the definition according to its own needs and when the definition is taken by the society to which an old person belongs. The point is that the difference refers to the fact that gerontology defines ageing according to a positive criterion while society defines old people as the population group who move from the sphere of active work to a social category of retired people. It is especially important to stress because a great number of individuals face such defined ageing, based on the drastic experience differences because of the change in life style after leaving the sphere of work, as opposed to people who can be classified as old people after reaching a certain life period from the perspective of gerontology (Milosavljevic, 2011).

Individual ageing has a biological and psychological, chronological and sociological, dimension. Biological ageing is defined as the assessment of characteristics and abilities of an individual in respect to the expected life period because of the diverse reasons of chronological grouping to which an individual belongs. Psychological ageing is defined in respect to individual adaptive capacities, i.e., in respect to the ability to adapt to changes in the life surroundings. If the individual adaptive capacity is well preserved, an individual has a lower psychological ageing as opposed to an average individual of his chronological age (Nešić, Nešić, 2008). Sociological ageing refers to social individual roles and habits in respect to other members of society: does an individual behave as younger or older in respect to the expectations of the society towards the members of his chronological group. These expectations vary in different societies (Rot, 1994). Sabol defines ageing in sociological sense as the biologically conditioned, but mostly socially and culturally fixed life phase in which an individual, depending on society, does not play the role of a mature man anymore, which means that he does not bear responsibility anymore, he does not make decisions and does not participate in social life and institutions (Sabol, 1984). 
While lacking a generally accepted theory of ageing, old age is actually impossible to define in a generally recognized way (Davidović, Kosanović, Barjaktarović, Trailov, 1998). It seems, nevertheless, that every theory of ageing must include the following features of ageing:

- Detrimental (decreasing function);

- Progressive (gradual advance);

- Endogenous (not resulting from the changed conditions of the environment);

- Universal (it refers to all individuals).

\title{
BIOLOGICAL CHARACTERISTICS OF AGEING
}

\begin{abstract}
"Is the cause of ageing a gradual loss of something which is vital for life sustenance, or is it the accumulation, the surplus, of something which is detrimental to the body? Loss or surplus - or both?"
\end{abstract}

In gerontology classical theories explain the causes of ageing by using different factors. According to one theory, old age results from the body exhaustion; according to another theory, it is a result of the string of mistakes in genetic programming because of the accumulated mutations or because of the decrease of the genetic control. According to the third theory, ageing is the result of the ageing of the immune system (Davidović, 1993). No matter how, the changes are different and numerous. The changes can be reflected in physical appearance, the function of the internal organs of human body, the decrease of motoric functions, but still ageing is to be differentiated from illness. Biological changes related to ageing are usually taken as "normally ageing changes". The loss of hair or grey hair, the lower capacity of training and strength, wrinkled skin, menopause, the loss of memory of the immediate events and many other forms of ageing are not illness. Other "normal" forms of ageing of the vital organs of human body increase the percentage of vulnerability to pathological changes. It is true, old age is threatened by diseases in the sense that illness accelerates ageing, and the ripe old age causes pathological changes in the body.

By analyzing literature dedicated to ageing and old age, it is easy to notice that there is not a common opinion about the time when old age starts. The unique, precise and unchangeable criterion 
which could separate the old age from the mature age and the adolescence, does not exist and it cannot be determined once and for all. It is ultimately relative and changeable according to places and periods of time. Hippocrates claimed that old age began at 56 but he did not separate the rights of old people to all life contents as compared to young people (Urošević, 2013).

The United Nations have defined the old as the ones who are over 60 . On one hand, the limit is low for the highly developed countries where the average life age is about 75, and, on the other hand, it is very high for the underdeveloped countries where the limit is 45 years of age (United Nations, 2000). According to gerontology, the old age is the period of an individual life after turning 65 . The references of gerontology further point to the classification of the old age (and this time according to the chronological, i.e., age criterion). Namely, the first phase comprises the early old age to which "young old" belong to and it lasts from 65 to 74 years of age. The second phase is the average age period, i.e., the age period with only the "old" population from 75 to 85 years of age. The third phase refers to the late old age with the "old-old", i.e., those who are 86 or more (Sumrak, 2010). The differences between people older than 65 are great. People between 65 and 75 are very similar to the population group of 55 to 65, first of all, in respect to their health, socioeconomic status, cognitive, developmental and physical features.

Still, old people are not homogenous group of people in a generational sense because what forms generations is what happens in the society during certain time in the observed group of people and the generational consciousness is formed according to common experience. A seventy-year old man and a hundred-year old man do not belong to the same generation. As a result, they may differ in demographic behavior, mortality and health culture (Devedžić, Stojiljković, 2012). 


\title{
PSYCHOLOGICAL CHARACTERISTICS OF AGEING
}

\author{
"Man is only a cane, \\ the feeblest creature in nature, \\ ... but a thinking cane" \\ Blaise Pascal
}

In the above cited motto by Blaise Pascal, French scientist, writer, and philosopher, and one of the most controversial philosophers of the West, the whole judgment of opinion is located. This is the key term which separates and favors man primarily as different from other living beings, embodied by the power of judgment about the purpose of his existence where the specific feature of ageing to which man is exposed as to destiny appears (Paskal, 1991).

During the process of biological ageing of the body, psychological changes appear which are determined by the very process of ageing as well as by the disease of the organic systems. It is evident that the old age brings the increase of the role of the interoceptive apparatus so that messages and impulses within the body are detected easily, with a fast reaction, and the symptoms of different diseases and disorders are noticed easily (Petrović, 1989).

old age brings the decrease of emotional ties with people and objects in the surroundings, the reduction of capacities to integrate external influences as well the importance of satisfying personal needs. These changes start in the middle age and are intensified till the old age (Jung, 1973). The cause of this is the change of attitude toward oneself and partly the change of attitude to the external world. The ultimate result is the retreat of an old person from the active engagement in the external world and separation from feelings and excitement. In order to preserve the balance between the motivational needs and the knowledge of the external world and the self, an old person clings to "cognitive reconstruction" (Nešić, Nešić, 2008).

According to Queen, when they have to face difficulties, old people are often "bad-tempered, angry, too demanding in order to secure attention and sometimes even hysterical" (Queen, Gruener, 1940). In some cases, an old person retreats into neurosis, fantasy, and even psychosis, in which he/she is satisfied with thinking about the past when he/she was the focus of attention or was successful at work. Separovic contends that the frequency of suicide increases 
with ageing. He thinks that it is the result of social isolation, weak ties with the family, the feeling of loneliness and the termination of every working activity (Šeparović, 1985).

The weakness of intellectual functions is typical of the old age but it is faster with people of the lower intellectual potential, while people with the high intellectual potential lose their capacities more slowly. Then, we can speak about "the crystallization of knowledge". As a matter of fact, premorbid features and the way of life in adolescence and mature age are most important for the quality of life and healthy behavior in the old age. It proves that people with harmonious and active life, who fulfill their duties, reach a peaceful and tranquil old age. Cicero especially insisted that various virtues in the old age such as better judgment, tolerance, wisdom, balance ... could be seen in old people who had that virtues throughout their life and were persistent both intellectually and physically. Cicero contends that the old age should be resisted as you resist illness and its weakness should be replaced by strong will because, apart from helping the body, the power of spirit and heart, since they can be extinguished in the old age like the lamp which is not supplied with oil, should be even more assisted (Ciceron, 1955).

So, it is very important to realize that the pattern of experience of the physiological process of the loss of strength could be substituted with the strong will animation, as a consciously guided and controlled intellectual impulse, which is, otherwise, a very effective weapon for accepting and transcending bodily weakness in a reasonable way (Petričković, 2011). We should be "aware of our being while facing ourselves; therefore, we should be true helmsmen of life and are not to allow our existence to lose its meaning. In life, we should allow for a certain brevity and adventure since we are going to lose it, all the same, in the best or in the worst case." (Niče, 1987).

One could wonder why then the old age should be exempted from childhood or youth as an age of possible working activities, which is witnessed by old people who were not only slow and immobile but also recognizable and taken as examples of having a will to work, always mobile and awake as they were in the previous phases of life. These are old people, young in their spirit, who are still eager to learn and discover, like Solon, who praises his ageing as a source of knowledge in his poems, or Cicero, who, in his late years, after not being able to learn to play the lyre as Socrates played, learned Greek with such zeal as if he had quenched his need for thirst with this learning as he himself said. Here it is worth mentioning Plato, who 
died in 81 and was still active writing, or Isocrates, who wrote the famous Panathinaikos, as he said, in his 94, and then lived for another five years like his teacher Georgias the Leontine, who was 107 and did not stop researching and writing. He worked till the end of his life bearing two great burthens: old age and poverty, almost looking forward to them, being industrious like Aeneas; then Sophocles who wrote tragedies till his old age and a great number of thinkers like Homer, Hesiod, Simonides, Socrates, Pythagoras, Democritus, Xenocrates, Zeno, Cleanthes, Diogenes and many others whose spiritual activity lasted as long as their life in spite of ageing (Petričković, 2012).Should one make a comment on this life vitality for productive creation?

If we are to talk about periods and phases of ageing, it is believed that there are many popular theories about the nature of human life in some phases from birth till death. One of these theories differentiates between seasons and life stages. So, the spring is the childhood and the youth, as the time of blooming in nature and human life. The summer is compared to the mature age. The fall is the late maturity, as the time of gathering crops in nature and human life. In the end, the winter is the time of decline and death (Tadić, 2003). This analogy is the poetic representation of human life course, but it is at the same time the simplification of the complexity of human life though it is evident that man is getting older in the three-quarters of his life.

According to a Hindu belief (Smiljanić, 1987), most of the people have four inclinations. They mostly correspond to man's stage of life. Childhood embodies the desire for satisfaction. It remains present in later life too. In the youth and the middle age, it is the impulse for success that is dominant. This impulse refers to professional and social achievements. In the mature age, it is the sense of duty that prevails. Man takes care for his off-springs and his parents. At the end of life, the most important impulse is to understand the meaning of life. At the same time, man tries to free himself from the impulse for satisfaction, success, and the sense of duty, i.e., from those impulses which were dominant in the previous phases of life (Nešić, Nešić, 2008). 


\section{SOCIOLOGICAL CHARACTERISTICS OF AGEING}

"...For the respect is not to be achieved suddenly by grey hair and wrinkles, but the honestly led life gathers the most beautiful fruits of human respect."

Cicero

The sociological dimension of the old age means the observing of the old age as a social category on which specific relations between the society and old people are based. Since we talk about relations, about something that is dynamic and changeable, it should be mentioned that the old age is not a permanent scientific category which could be abstracted from the concrete social conditions and made objective. Accordingly, the old age, in the sociological sense, is defined as the biologically conditioned, but mostly socially and culturally fixated life phase, where an individual, according to the society's tendencies, does not play the role of an adult, which means that he does not bear responsibility, does not make decisions and does not participate in social life and institutions (Sabol, 1984).

In the 1980s, a few American sociologists still tried to single out some features of the largely accepted social attitude to old people. In the old age, there is a commonly present tendency to give advice and supervise other people. Saving for old days is almost universally spread even when such an effort does not give expected results (Cowgill, Holmes, 1972). In the old age, a man loses initiative, his working abilities decline even before he gets retired.

The issue of the social meaning of ageing should be considered in the wider context. Gerontology does not only study the physical process of getting older but also the social and cultural dimensions related to it. It is about the two contradictory processes. During the whole history of civilization, old people have had a special place because of their experience, knowledge and resourcefulness in social roles which the young had still to learn. On one hand, old people in modern societies have a lower status and less power than in post-modern cultures. In these cultures, like in modern, non-Western societies (India, China), it was thought that the old age brings wisdom, and the oldest people in these communities were the main factors in making decisions (Pešić, 2007). 
In its mature age, modern civilization takes with itself something very contradictory. In the society that constantly changes, the accumulated knowledge of the old looks rarely as the source of wisdom to the young and more as something old-fashioned. The reason is in the demographic component as well as in the social, class, and family features. In such societies, the main difficulty is the social isolation of the old and their retreat from active social life. The old are often limited in their participation in the social, economic and political life, which is not enough to influence different spheres of social life though, as population, they are not a minority. There is a conflict between the old who want certain social roles and the young who do not want to let them play these roles. That's why some sociologists compare the position of the old with the position of the adolescents. Their difficulties to adapt to social demands are similar. Both groups feel useless and realize that their desires are not recognized.

In that sense, the life of the old often has a marginal position as the life of people "on the edge" of social life. The influence of their everyday activities on social life cannot be defined as dominant in the process of decision making which could change reality (Kostić, Đorđević, 2004). This entails the need to overtake a number of social measures, on one hand, and, on the other hand, there is a question what to do when an old person becomes unproductive. In some countries, it is possible that the old can undertake some activities to feel useful and needed by a social community. Thus, for example, according to the law of Inks, the old, who could not do any other job, protected the crops from birds and grasshoppers. In other primitive cultures, old people were expected to spin tales as entertainers and instructors who maintained social morality. In civilizations based on oral tradition, the old were the treasure of knowledge. In Africa, where there are no written documents, the death of old people equals the destruction of a library (Pešić, 2007).

According to Rose, old people have a need to socialize because of partial or complete isolation. The subculture of the old is created with their special associations, norms and customs (Rose, 1962).

Still, like children, old people need the same family assistance and support for a proper life. It is paradoxical that contemporary society offers all scientific achievements in child protection, before and after birth, during their growing-up and education, but social protection in the old age is missed out or it is understood as burthen or charity. Social protection in the old age cannot be an act of good will 
but the right to the previous work. It is necessary to stress that the problems of old people reflect the possibilities and needs of the process of ageing, on one hand; on the other hand, they reflect the society which is responsible for the old people.

\section{THE DEMOGRAPHIC REVOLUTION}

The previous century was the century of the world population growth; according to scientists, the $21^{\text {st }}$ century will be the age of population ageing. Demographic ageing becomes a dominant phenomenon which attracts more and more attention of the scientific research and wider publicity. There are several basic reasons why ageing and the level of demographic ageing stopped becoming the subject of the interest of demographers. First, it is evident that it is about one inevitable and common tendency which will pertain to all societies sooner or later, and second, the process of demographic ageing with its level and the intensity initiates a string of open issues which will require from every country specific and very precise answers, depending on the economic development and the perspectives of the future demographic development above all. Among the rest, the process of the ageing of population is the result of the changes within the death rate and the length of human life. The achievements in medicine, pharmacology, genetics, public health, healthy life style promotions, point to the fact that the length of human life will increase and the population of the old people will multiply.

All the changes of the length of human life influenced the demographic pyramid. The difference between the old and the young population is greater and greater: from the "bottom-heavy" pyramids with the wide base to the "top-heavy" pyramids with the wide tops. In addition, the balance moves to one side since the old population is mainly female! Throughout human history, the pyramid was always with "the wide base" and lately it has got the shape of "the onion" in developed countries, i.e., half of the population are the old people. (Counicil of Europe, 2004).

The aging of the population as an irreversible process, primarily binds to the developed countries of Europe, North America, Oceania and Japan, although it is present in the less developed regions of the world. The group developed regions of the world in the late 20th century, was the oldest inhabitants of Europe, so that this continent 
is rightly called the "old". Among the 25 demographically oldest countries in the world with the exception of Japan, all of Europe, including the Serbia. (Stevanović, 2006). When it comes to the aging of the population, at the beginning of the 21st century, demographers have pointed to the alarming fact that Serbia was rapidly transformed from a demographic youth of the early 20th century (seeing the whole territory) to express senilisation, particularly in certain regions. With a sixth older than 65 years and the average age of the population of 40.2 years, Serbia has among the oldest populations in the world (Petrovic, Jovanović, 2012).

Thus, Serbia (without Kosovo and Metohija) to $16.5 \%$ (the share of persons older than 65 years in the total population) is within the group of five oldest demographic countries of the South-European area (after Italy 18,2\%, Greece 17,3\%, Spain 17,1\% Portugal 16,7\%) and in wider European area, preceding Serbia are Germany $(17,5 \%)$, Sweden (17,2\%), Bulgaria and Belgium with 17\% (Counicil of Europe, 2004).

The fast growth of "the old-old" causes the appearance of new phenomena because we know that after 75, psycho-physical changes as well as invalidism and the decline of capacities for an independent life and the need for special forms of assistance and support occur. The growth of old population is the great challenge for social system security, especially the retirement funds, the health system and the social protection system. It is known that the old people are a special population group which has its special rules.

The results of projections till 2050 point to the fact that, in a demographic sense, the first half of the $21^{\text {st }}$ century will be the age of the old. The process of demographic ageing would affect all areas of the world; the ageing would be faster in the developed countries, but based on intensity, it would be faster in the undeveloped countries than it is now. The projections for 2050 predict that the participation of older than 65 would be $16,2 \%$, and in developed countries $25,7 \%$ (United Nations, 2010). The analysts point out to the fast growth of the number of very old people. So in 1998, 66 million people were over 80 , and in fifty years it is expected to have 370 million of old people and about 2 million of people who are one hundred. The concrete results of the projection in European region show that the process of demographic ageing is again very high in the population of the whole South-Europe and in many countries there. So, in 2050 every third inhabitant $(33,5 \%)$ of South-Europe would be older than 65 (Stevanović, 2006). In respect to ageing, Ser- 
bia would follow European trends completely while the process of ageing would be more outstanding in some aspects which would bring it to the group of oldest countries in fifty years. Projected population older than 65 years is shown in Table 1 (UN, 2014).

\begin{tabular}{ccc} 
YEAR & (THOUSANDS) & \\
2010 & 1325 & 13.7 \\
2015 & 1413 & 15.0 \\
2020 & 1595 & 17.4 \\
2025 & 1705 & 19.2 \\
2030 & 1758 & 20.5 \\
\hline
\end{tabular}

TABle 1: Projected Population Older than 65 Years, the CASE OF SERBia (UNITED NATIONS, 2014)

If you would like criterion reached age demographic took median age, ahead of Serbia to 2050 . contained only a few countries (Table 2) (UN, 2014).

\begin{tabular}{ccc} 
RANK & COUNTRY & MEDIAN AGE \\
1 & Spain & 55,2 \\
2 & Slovenia & 54,1 \\
3 & Italy & 54,1 \\
4 & Austria & 53,7 \\
5 & Armenia & 53,4 \\
6 & Japan & 52,4 \\
7 & Czech Republic & 52,4 \\
8 & Greece & 52,3 \\
9 & Serbia (without Kosovo and & 52,1 \\
10 & Metohija) & 52,0 \\
\hline
\end{tabular}

TABLE 2: THE MEDIAN AGE OF TEN DEMOGRAPHICALLY OLDEST COUNTRIES IN THE WORLD 2050 (UNITED NATIONS, 2014) 
Bearing in mind this situation it is necessary to actively work on the implementation of the national strategy on aging, which was adopted in 2006 in Serbia. Its application assumes synchronous operation of different institutions and organizations in society, and the struggle to change the social consciousness in terms of developing intergenerational solidarity, respect the value of human dignity of the elderly and their role in the modern (Rašević, 2007).

\section{CONCLUDING CONSIDERATIONS}

"Before it strikes us, the old age is something that refers to other people nly. In that way we can understand why society succeeds in diverting us to see ourselves as similar to the old!"

Simone de Beauvoir

The impression is that contemporary man deals with the issue of ageing more intensely than it was done in the past. The reason for that could be the fact that man experiences a great broadening of consciousness in the social and cultural context and, therefore, deals with such issues today, on one hand; on the other hand, man does not want to think about the essential issues of life but he wants to change the conditions of living, and, by using scientific achievements, he may find the solution for his problems: illness, ageing and death.

Exploring the concept of ageing, one stresses the quality and length of life which are advanced by the interaction of three factors: social engagement and participation, the reduction of illness and the advance of the levels of psychic and intellectual functioning (Victor, 2005).

Taking everything into account, we can conclude that today's world is not the world of the old or for the old. If you take into account the fact that the old age is the age of the reduced physical and psychological abilities and the higher rate of invalidism, and demographic ageing as the increase of population who is dependent (in economic, social and medical sense), then these tendencies can be the source of worry. It is important to emphasize that in all these efforts should prevail universal values that connect the old age and disability, which is often her companion, as the two ubiquitous phe- 
nomenon in modern civilization: human rights and dignity, nondiscrimination and the promotion of solidarity among people.

From the perspective of human potential of social development, the negative balance of demographic dynamics is a serious problem because no demographic substrate does not state or the society. Thus, countries are faced with an old population, largely supposed to care about their future, in which "there will be no one to give birth and to work", and pressures on the budget will undermine economic stability. It is therefore proposed numerous efforts in certain domains, among which is the most important change stereotypes related to age and older. Age, as well as special medical and sociological phenomenon, it reflects the way in which they are defined life roles, as the degree of readiness for their acceptance. In the developed countries, this group of people is not treated automatically as passive or "the society's burthen". On the contrary, there are efforts directed to social inclusion and the prolonging of "healthy life".

The impeccable natural harmony does not simply allow to neglect the last phase of life. Along other acts of the life stage (childhood and youth), the old age should be balanced and given wholeness. That wholeness has its end, its final act, like any other notion in the world and in human psyche, in the right time when life matures as fruit in the tree which falls and dries after having ripened. Taking this into account, there is a question: if man would bear his old age more easily if he turned eight hundred instead of eighty? (Cicero, 1955: 209)

In the end, the approaching moment of man's departure from this world is not sufficient enough to turn the old days into apathy because eternity is not as important as eternal vitality and every day should be spent as if it were the eternity of the existing moment.

\section{REFERENCES Ciceron, M. T. (1955). O starosti. Beograd: Kultura.}

Council of Europe. (2004). Recent Demographic Developments in Europe. Strasbourg: Council of Europe Publishing.

Cowgill, D., \& Holmes, L. (1972). Aging and Modernization. In Social Gerontology: Old Age Across Cultures and Time.

Davidović, M., Kosanović, M., Barjaktarović, N. i Trailov, D. (1998). „Starost i starenje”. U M. Davidović (ur.), Gerijatrija (str. 3-22). Beograd: Medicinski fakultet Univerziteta u Beogradu, NT Club.

Davidović, M. (1993). „Nasledna osnova starosti i starenja”. Gerontologija, 1, 65. 
Devedžić, M. i Stojiljković, J. (2012). „Novo poimanje starosti - prospektivna starost". Stanovništvo, 1, 45-68.

Jaspers, K. (2008). Svetska istorija filozofije. Beograd: Fedon.

Jung, K. G. (1973). Čovek i njegovi simboli. Zagreb: Mladost.

Kastenbaum, R. (1986). Starenje. Zagreb: Globus.

Kostić, M. i Đorđević, R. (2004). „Viktimizacija starih osoba kao pripadnika posebne marginalne grupe". U Marginalne grupe i viktimizacija (str. 3-11).

Milosavljević, Lj. (2011). „Upravljanje vremenom i njegovo vrednovanje kod starijih pripadnika društva". Antropologija, 11(1), 143-159.

Nešić, V. i Nešić, M. (2008). „Socijalnopsihološki i psihofiziološki aspekti starenja i starosti". Teme, 32(3), 577-584.

Niče, F. (1987). Šopenhauer kao vaspitač. Beograd: Grafos.

Paskal, B. (1991). Misli. Beograd: Mediteran.

Pešić, Lj. (2007). Socijalni i zdravstveni problemi osoba u poznim godinama života. Acta Medica Medianae, 46, 45-48.

Petričković, M. (2011). Etika socijalnog rada. Beograd: Socijalna misao.

Petričković, M. (2012). „Socijalni rad u rodnoj pliromi starenja na primeru domske porodice". Socijalna misao, 1, 29-48.

Petrović, D. (1989). Psihički poremećaji u starijem životnom dobu. Beograd: Medicinska knjiga, Svetlost.

Queen, S.A., \& Gruener, J.R. (1940). Social Pathology. (pp. 100-101). New Jork: Thomas Y. Crowell Company.

Rose, A. (1962). The subculture of the Aging: A Topic for Sociological Research. The Gerontologist, 2, 123-127.

Rot, N. (1994). Osnovi socijalne psihologije. Beograd: ZUNS.

Sabol, J. (1984). „Sociološki vid starosti”. Bogoslovska smotra, 53(4), 235-245.

Smiljanić, V. (1987). Psihologija starenja. Beograd: Zavod za udžbenike i nastavna sredstva.

Stevanović, R. (2006). „Južna Evropa: demografski najstarija regija evrope i sveta". U Strukturne poromene i demografska kretanja zemalja Južne Evrope. Niš: Ekonomski fakultet.

Sumrak, D. (2010). Opšta gerontologija - Antropologija starosti. Beograd: Socijalna misao.

Šeparović, Z. (1985). Viktimologija - studije o žrtvama. Zagreb.

Tadić, Lj. (2003). Zagonetka smrti - smrt kao tema religije i filozofije. Beograd: Filip Višnjić. 
Urošević, R. P. (2013). Bonton starenja ili demanti o starenju. Beograd: Gerontološko društvo Srbije, Čigoja štampa.

United Nations. (2000). World Population Prospects. The Revision. Preuzeto sa http://esa.un.org/unpd/wpp/index.htm

United Nations. (2010). World Population Prospects: The 2010 Revision. Preuzeto sa http://esa.un.org/.

Victor, R. (2005). The Social Context of Ageing. London: Routledge. 
ТАњА Т. ПРОДОВИЋ

УНИВЕРЗИТЕТ У КРАГУЈЕВЦУ, ФАКУЛТЕТ МЕДИЦИНСКИХ НАУКА

ДРАГАНА ИГњАТОВИЋ РИСТИТ

КЦ КРАГУЈЕВАЦ, КЛИНИКА ЗА ПСИХИЈАТРИЈУ

БИљАНА ПРОДОВИЋ МИЛОЈКОВИЋ

УНИВЕРЗИТЕТ У НИШУ, ФИЛОЗОФСКИ ФАКУЛТЕТ

БИО-ПСИХО-СОЦИЈАЛНИ КОНЦЕПТ СТАРОСТИ

Тематски, рад садржи ठитно питање људске егзистенције, крајње сложен и тајновит феномен човековог старења. Старе осо$\delta$ са свим својим ठиолошким и психолошким особинама као и обележјима свог социјалног положаја и осталим аспектима, неисцрпни су повод стручног суочавања, како лекара тако и социолога. Насупрот уобичајеном песимистичком ставу о старењу и старости, овде се у оквирима хуманистичко-социјалног рада указује на поседовање свести да се човекова немоћ ठесконачног ठитисања може превазићи поседовањем смисла и лепоте живљења. Разрађујући концепт старења наглашава се дуговечност и квалитет живота, који су унапређени интеракцијом три групе фактора: друштвеном ангажованошћу и учешћем, редукцијом ठолести и унапређењем високих нивоа психичког и менталног функционисања.

Кључне речи: старост, старење, демографија, социјални проблем, здравствени проблем.

320 Tanja T. Prodović, Dragana Ignjatović Ristić, Biljana T. Prodović Milojković 